\title{
Growth and mineral composition of grape-vine rootstock cultured in vitro with different levels of ammonium nitrate
}

\author{
A. TRONCOSO, A. VILlEGAS ${ }^{1}$, C. MAZUELOS and M. CANTOS \\ Instituto de Recursos Naturales y Agrobiología de Sevilla, CSIC, B.P.O. 1052, E-41080 Sevilla, \\ Spain. ${ }^{1}$ Colegio Postgraduados, MEX-56230 Chapingo, México
}

Key words: grape-vine, in vitro culture, nitrogen nutrition

\begin{abstract}
Growth and mineral composition of grape-vine explants (13.3 EVEX rootstock) cultured on a basal medium with $10.4 \mathrm{mM}$ of $\mathrm{NO}_{3}^{-}$, and respective additions of 5, 10, 15, 20 and $25 \mathrm{mM}$ of $\mathrm{NH}_{4} \mathrm{NO}_{3}$ were analysed.

Low $\mathrm{N}$-availability $(10.4 \mathrm{~m} M)$ induced low shoot formation. Addition of $\mathrm{NH}_{4} \mathrm{NO}_{3}$ up to $15 \mathrm{~m} M$ increased number, quality and $\mathrm{N}$ levels of shoots. Further increase of $\mathrm{N}$ in the medium induced very high contents of $\mathrm{N}$ and water in tissues, and led to a bad shoot quality (large and abnormally shaped leaves and dark colour-fragile tissues, difficult to handle in further propagations). The content of $\mathrm{K}$ in explants was negatively affected by the concentration of $\mathrm{NH}_{4} \mathrm{NO}_{3}$ in the substrate and by the level of $\mathrm{N}$ in tissues.
\end{abstract}

\section{Introduction}

In a previous work (Troncoso et al., 1988) the influence of $\mathrm{N}$ on growth and mineral composition of grape-vine rootstocks $41 \mathrm{~B}$ and 161-49, were studied. Although the response of the rootstock 161-49 was much more active than that of $41 \mathrm{~B}$, increasing $\mathrm{N}$ in the medium increased number, size and $\mathrm{N}$ contents of shoots and decreased formation of callus in both rootstocks, but excess of $\mathrm{N}$ produced non-desired shoots.

The aim of the present work was to study the response to $\mathrm{N}$ of a new grape-vine rootstock (13.3 EVEX) from the "Estación de Viticultura y Enologa de Jerez (Spain)", and to study more in detail the influence of $\mathrm{N}$ availability on the quality and mineral composition of shoots.

\section{Materials and methods}

Homogeneous, $10 \mathrm{~mm}$ long explants of grapevine rootstock 13.3 EVEX were cultured at a temperature of $25^{\circ} \mathrm{C}$, light intensity of 2500 lux and $16 \mathrm{~h}$ photoperiod.

The treatments were:

- Control, with basal substrate (Table 1);

-Five $\mathrm{NH}_{4} \mathrm{NO}_{3}$ concentrations added to the

Table 1. Composition of the basal nutritive medium

\begin{tabular}{lllclr}
\hline $\begin{array}{l}\text { Chemical } \\
\text { compound }\end{array}$ & $\mathrm{m} M$ & $\begin{array}{l}\text { Chemical } \\
\text { compound }\end{array}$ & $\mu \mathrm{M}$ & $\begin{array}{l}\text { Chemical } \\
\text { compound }\end{array}$ & $\mu$ M \\
\hline $\mathrm{KNO}_{3}$ & 7.91 & $\mathrm{MnSO}_{4} \cdot 4 \mathrm{H}_{2} \mathrm{O}$ & 5.0 & M-inositol & 27.75 \\
$\mathrm{Ca}\left(\mathrm{NO}_{3}\right)_{2} \cdot 4 \mathrm{H}_{2} \mathrm{O}$ & 1.27 & $\mathrm{H}_{3} \mathrm{BO}_{3}$ & 100.0 & Thiamine & 2.96 \\
$\mathrm{KH}_{2} \mathrm{PO}_{4}$ & 1.25 & $\mathrm{ZnSO}_{4} \cdot 7 \mathrm{H}_{2} \mathrm{O}$ & 30.0 & 6 -BAP & 4.43 \\
$\mathrm{MgSO}_{4} \cdot 7 \mathrm{H}_{2} \mathrm{O}$ & 1.50 & $\mathrm{Na}_{2} \mathrm{MoO}_{4} \cdot 2 \mathrm{H}_{2} \mathrm{O}$ & 1.0 & IBA & 0.48 \\
$\mathrm{FeSO}_{4} \cdot 7 \mathrm{H}_{2} \mathrm{O}$ & 0.09 & $\mathrm{CuSO}_{4} \cdot 5 \mathrm{H}_{2} \mathrm{O}$ & 0.1 & Sucrose & $30 \mathrm{~g} . \mathrm{L}^{-1}$ \\
$\mathrm{Na}_{2} \mathrm{EDTA}$ & 0.10 & $\mathrm{CoCl}_{2} \cdot 6 \mathrm{H}_{2} \mathrm{O}$ & 0.1 & Agar & $6 \mathrm{~g} \cdot \mathrm{L}^{-1}$ \\
\hline
\end{tabular}


Table 2. Influence of $\mathrm{NH}_{4} \mathrm{NO}_{3}$ on number, growth, hydration and mineral composition of shoots

\begin{tabular}{|c|c|c|c|c|c|c|c|}
\hline \multirow{2}{*}{$\begin{array}{l}\mathrm{NH}_{4} \mathrm{NO}_{3} \\
\text { added } \\
(\mathrm{m} M)\end{array}$} & \multirow{2}{*}{$\begin{array}{l}\text { Shoots per } \\
\text { explant } \\
\text { (average) }\end{array}$} & \multirow{2}{*}{$\begin{array}{l}\% \text { of } \\
\text { shoots } \\
>10 \mathrm{~mm}\end{array}$} & \multirow{2}{*}{$\begin{array}{l}\text { Fresh } \\
\text { weight } \\
\text { (mg/plant) }\end{array}$} & \multirow[t]{2}{*}{$\%$ hydration } & \multicolumn{3}{|c|}{ Mineral composition } \\
\hline & & & & & $N(\%)$ & $\mathrm{K}(\%)$ & $\mathrm{Fe}(\mathrm{mg} / \mathrm{kg})$ \\
\hline 0 & $2.60 \mathrm{a}$ & $25.93 \mathrm{a}$ & 125 & 81.25 & 1.32 & 2.95 & 85 \\
\hline 5 & $4.01 b$ & $43.09 \mathrm{~b}$ & 220 & 82.50 & 2.54 & 2.52 & 161 \\
\hline 10 & $5.76 \mathrm{~b}$ & $43.84 b$ & 345 & 82.92 & 3.39 & 2.20 & 234 \\
\hline 15 & $5.00 \mathrm{~b}$ & $45.84 b$ & 539 & 83.23 & 4.03 & 1.77 & 336 \\
\hline 20 & $5.37 \mathrm{~b}$ & $51.19 \mathrm{~b}$ & 541 & 85.50 & 4.79 & 1.49 & 431 \\
\hline 25 & $5.49 b$ & $49.74 b$ & 499 & 89.75 & 5.50 & 1.48 & 530 \\
\hline
\end{tabular}

Identical letters indicate non-significant difference $(P<0.05)$ by the Tukey test.

control medium: 5, 10, 15, 20 and $25 \mathrm{mM}$ of the salt, respectively.

Each treatment involved 24 explants $(8 \times 3$ replicates).

After 30 days, the number and size (per cent under and over $10 \mathrm{~mm}$ ) of shoots, fresh and dry weight, tissue hydration (fresh weight minus dry weight / fresh weight $\times 100$ ) and mineral composition (Pinta et al., 1969; 1973) of explants were analysed. To determine the quality of shoots, size and shape of leaves, colour and fragility of tissues, and facility to handle in further propagation processes were also considered.

\section{Results and discussion}

As shown in Table 2, low concentration of $\mathrm{N}$ in the medium (control) produced low number and size of shoots. Additions of $\mathrm{NH}_{4} \mathrm{NO}_{3}$ up to 10 $\mathrm{m} M$ increased both number and length of shoots, and higher $\mathrm{N}$ additions did not cause further increase of these characteristics. The rootstock 13.3 EVEX showed a lower response to $\mathrm{N}$ than 161-49 and $41 \mathrm{~B}$ (Troncoso et al., 1988).

Addition of $\mathrm{NH}_{4} \mathrm{NO}_{3}$ to the substrate up to 15 $\mathrm{m} M$, resulted in a linear increase of shoot fresh weight $(r=0.99)$. Further increase in $\mathrm{N}$ addition had a negative effect on the weight of shoots. Addition of $\mathrm{NH}_{4} \mathrm{NO}_{3}$ resulted in increased hydration percentage $(\mathrm{r}=0.93), \mathrm{N}$ content $(\mathrm{r}=$ $0.97)$ and $\mathrm{Fe}$ content $(\mathrm{r}=0.99)$ of explant tissues. In contrast, the levels of $\mathrm{K}$ in tissues were negatively affected by $\mathrm{NH}_{4} \mathrm{NO}_{3}$ additions $(\mathrm{r}=$ $-0.96)$ and by $\mathrm{N}$ in tissues $(\mathrm{r}=-0.99)$. The other nutrients considered were not clearly influenced by $\mathrm{N}$, their average levels being 3.3 $\mathrm{g} / \mathrm{kg}$ for $\mathrm{P}, 5.8 \mathrm{~g} / \mathrm{kg}$ for $\mathrm{Ca}, 3.0 \mathrm{~g} / \mathrm{kg}$ for $\mathrm{Mg}, 43$ $\mathrm{mg} / \mathrm{kg}$ for $\mathrm{Cu}, 124 \mathrm{mg} / \mathrm{kg}$ for $\mathrm{Mn}$, and 241 $\mathrm{mg} / \mathrm{kg}$ for $\mathrm{Zn}$, all on a dry weight basis.

$\mathrm{N}$-applications clearly affected the quality of shoots. Low $\mathrm{N}$ availability produced few and short shoots. Addition of 10 or $15 \mathrm{mM}$ of $\mathrm{NH}_{4} \mathrm{NO}_{3}$ gave more, larger, well-formed shoots, with normally sized-shaped leaves, intensive green colour and flexible tissues, very easy to handle and with good response in further propagations. Larger $\mathrm{N}$-additions, $20 \mathrm{~m} M$ and more, produced non-desired shoots with very dark colour, abnormally large shaped leaves and fragile tissues, difficult to handle in further propagation processes.

\section{References}

Pinta M et Membres du Comité Inter-Instituts d'Etude des Techniques Analytiques du Diagnostic Foliare 1969 Méthodes de référence pour la détermination des éléments minéraux dans les végetaux: $\mathrm{N}, \mathrm{P}, \mathrm{K}, \mathrm{Ca}, \mathrm{Mg}$. Oléagineaux 24, 497-504.

Pinta $\mathbf{M}$ et Membres du Comité Inter-Instituts d'Etude des Techniques Analytiques du Diagnostic Foliare 1973 Méthodes de référence pour la détermination des éléments minéraux dans les végétaux. Determination des éléments $\mathrm{Ca}, \mathrm{Mg}, \mathrm{Fe}, \mathrm{Mn}, \mathrm{Zn}$ et $\mathrm{Cu}$ par absortion atomique. Oléagineaux 28, 87-92.

Troncoso A, Villegas A, Mazuelos C and Cantos M 1988 Influenza del livello di azoto $\left(\mathrm{NH}_{4} \mathrm{NO}_{3}\right)$ del mezzo sullo sviluppo e composizione minerale di meristemi di vite "in vitro". III Convegno sui portainnesti della vite. Potenza (Italia). NOTAE Accademia Italiana della Vite e del Vino 5,144 . 